\title{
13. Bamboo Knives, Bows, and Waterfalls: The Presentation of "Traditional Knowledge" in Melpa Kang Rom, Duna Pikono, and the Works of Hesiod and Virgil
}

\author{
Andrew Strathern and Pamela J. Stewart
}

\section{Introduction}

Poetry and prose are often conventionally contrasted. Poetry is seen as an elevated form of language, conveying feelings and insights in rhythmic forms. Prose is often seen as the vehicle for conveying "rational thought," and also as mundane, ordinary use of language. Of course, these stereotypes are quite inaccurate. There are many different genres and uses of both prose and poetry. Prose can express complex emotions and use metaphors and similes; poetry can read like a quiet conversation, imparting local information. The rigid division between prose and poetry may perhaps be peculiar to literate cultures. In oral cultures clear distinctions are made between different ways of speaking: ordinary conversation, rhetorical speeches, genres of songs or songs to accompany particular occasions, for example (Strathern and Stewart 2000, 2005a; Stewart and Strathern 2000, 2002a, 2005a). Songs, nevertheless, may convey much practical and social information, as well as expressing and evoking emotions. And in cultural contexts where songs are important and are transmitted over time, these songs may continue to convey such information beyond the historical times in which the information or knowledge was originally created. This process becomes particularly important when rapid social and cultural changes entail alterations of knowledge or a risk of such alterations.

It is not only practical knowledge that may be preserved in this way. We have previously argued for the pikono ballad form among the Duna of the Southern Highlands Province in Papua New Guinea that "Pikono ballads keep alive and creatively rework cultural themes of the Duna past" (Stewart and Strathern 2005b:86). In particular, we noted that, although initiation rituals were abandoned as a result of early colonial influence during the 1960s in the Duna area, "the themes of maturation, of romance and the favorable influence of the female spirit who presided over the palena [initiation houses built in the bush areas] are 
all retained and expressed in the pikono" (ibid.:94). Here we apply this insight further to the extended transmission of forms of practical knowledge-forms which themselves are also imbued with social meanings.

Recently, an anthropologist working with findings from cognitive science and commenting on Bronislaw Malinowski's work on the language usages in Trobriand magical spells (Sørensen 2007) has raised the question of "why ritual forms of language should be deployed to convey practical kinds of knowledge that could, he suggests, be conveyed with greater facility outside of such ritual contexts" (Strathern and Stewart 2007a:xii). Answering Sørensen's question briefly from his own exposition, we noted how "one Trobriand magician's spell encapsulates in itself a whole imagined narrative of agricultural activity in which both the dangers and the counteractions against these dangers are vitally delineated" (ibid.). That is, the spell is actually a vitally condensed recipe or "model for all the practical actions needed to succeed in the agricultural cycle" (ibid.). The spell is an imaginative projection, a representation, and a performative act, an enactment of power.

We went on, in this passage to extend the basic argument to balladic forms from the Papua New Guinea Highlands. These are not magical utterances in any direct sense, but they are composed in standard formulaic ways (as many oral epics are) and are delivered in an elevated and ritualistic style. Their style is comparable to the classic features of magical language delineated by Stanley J. Tambiah, who also drew his inspiration from Malinowski's Trobriands corpus (Tambiah 1968). These features include: redundancy (repetition), analogical predication (metaphor), and the building up of wholes from parts (metonymy). For the Papua New Guinea ballad forms we noted that in these also "representations of practical knowledge ... appear in highly condensed and imagistic forms which parallel in their characteristics the features that Tambiah ... identified" (Strathern and Stewart 2007a:xii). Finally, we suggested that "such presentations of knowledge undoubtedly gain a greater salience in people's consciousness because of their aesthetic appeal ... This process is underpinned by the systematic use of iteration, framing, and condensation which the poetic form itself generates" (ibid.:xiii). To reinforce our point, we argued further that similar reasons underlie the "poetic forms adopted by ancient Greek and Latin authors to convey practical forms of knowledge ... Hesiod's Works and Days and Virgil's Georgics would belong to this genre" (ibid.:xiii).

In the present paper we elaborate on these points with relevant examples, returning also at times to Tambiah's formulations. 


\section{Melpa ballads: Bamboo knives}

Melpa ballads (kang rom) are long narrative expositions of the actions of heroic figures belonging to the mythical past. The use of language in them is highly rhythmic and balanced. Only a few people have the skill to perform kang rom, and their artistic form is highly appreciated (Strathern and Stewart 2005a).

In earlier publications (Stewart and Strathern 2002a; Strathern and Stewart 2005b) we have given textual excerpts from these balladic forms. We draw on these here in order to illustrate our present argument.

In the ballad of the youth Miti Weipa, Weipa plans to go on a journey and he kills a pig and cooks it, ready to take it with him. The ballad gives a description of his actions, as well as of the notable size of the pig he is about to sacrifice:

\section{okl na klimba nitim e}

mok na purpur nitim e

Its belly hung down to the ground

Its feet shook with its own weight.

Weipa kills the pig by striking its forehead with a special club made from milik, a hardwood. He singes its hair off next, as is done customarily over a charcoal fire used to heat stones for the earth oven:

kng ndi kökli mon e

pona pokl raka rurum e

It was not like singeing its hair

More like clearing a field of weeds

so abundant and tangled was the hair on the surface of the pig's skin.

Then comes a characteristically fanciful section, a motif that is recurrent from one performance to another, which also contains a vital technical message. Weipa hears a noise coming from a thicket of nöngin plants nearby:

mel rakl kum rakl a

tekekl nggewa nggawa nilingila

mel rakl mel nambamel e

Temboka Mot elim nuimb e

Melpa Wat elim nuimb e 
Sung Tales from the Papua New Guinea Highlands

Two things like two fists

Banging away at each other

Mot of Temboka said he would eat

Wat of Melpa said he would eat

The image here portrays two kinds of bamboo knives, one from the Nebilyer Valley area (Temboka refers to this area and Mot is the name given to the knife) and one from the Central Hagen area (Melpa area, also used for the language of this area; Wat is the knife's name). Mot wins the struggle, and the ballad continues with a straight-out technical description of how to butcher a pig:

woint ndurum e ndoklnga ndoklnga

pendik mint e köng nitim a

ment a ndurum ndoklnga e

te mong e pokla rurum e

He cut the pig from tail to head

Laid bare the shoulder blade meat

He cut the pig from head to tail

And pierced the opening of its anus

Then follows another imaginative touch:

kng mint e nui mon e

nde katil möka murum e

It was not like meat for eating

It was like layers of pebbles on a river bank

These few passages, which are paralleled in many other parts of the ballad, indicate how technical information is ensconced inside metaphorical comparisons. The Melpa text in fact says, for example, "It was not meat for eating, It was pebbles on a bank," challenging the listener to make the leap from one image to another along with the performer. The background to this operation is that the sharpness of the bamboo knife is very important for making a clean cut. And the desire of the cutter to eat is projected onto the knife itself, which is given its own agency. The bamboo knife cuts better than steel, and gains its glory in doing so. After that it may be discarded because it is easily replaceable. Not everyone can wield it. Cutting pork is a special skill, requiring knife and human hand together to do their magic. The ballad catches this essential embodied truth, then embellishes it. In this, the balladic language follows the paths of magical language. 


\section{Duna ballads: Bows and waterfalls}

Duna pikono, like Melpa kang rom, are often centred on a young male protagonist and his search for maturation in life. We have given some specimens of pikono text in an earlier publication (Stewart and Strathern 2005b:90-93). The text sets up a scenario in which a youth and his sister are together. It explains that the youth was quite young and small, the wig he wore was not large but small, and his face was not yet painted with the stripes of yellow earth applied when boys used to emerge from the growth-houses in bush seclusion areas and dance before spectators, including unmarried girls. He decorated himself, therefore, as an uninitiated youth, and his father bought him a bow, a mark of hunting and manhood, to carry on his journey (the Duna language materials are given in Stewart and Strathern 2005b:90):

His father brought him something there

Brought him a bow and arrows he had made for the boy and gave it to him

He brought him a bow from Uru Saiya and gave it to that boy

He brought him a bow from Rukupa Rarope and gave it to that boy

And from Kewa Kikayea and gave it to that boy

The ballad goes on with a recitation of the names of places from which the bamboo fibres for the bowstring were gathered and given to the boy. All of the places named belong to the local landscape. Such names appear also in other sung performances, notably funeral laments sung by women. Each name contains condensed meanings as a focus of a type of resource in an environment where emplaced knowledge is significant (see Strathern and Stewart 2007b). The repetitions therefore enclose a memory bank of information, and the place names are ones that young men looking for materials to make a bow and bowstrings would find very useful. This example is also a plain list, without metaphor or metonymy, although in some ways the whole landscape is represented metonymically in its named parts; and the overall image of the bow is a metaphor or marker of the boy's journey into adulthood.

This same pikono sequence has a piece in which waterfalls appear:

Down below there a waterfall was splashing

Splashing on the wig of the boy

And eleven waterfall places are then enumerated, appearing mostly in pairs, sometimes with alliterative names:

Waterfalls from the rivers Yeati and Yease

Of Nali and Ukunali, waterfall noise splashing down. 
Waterfalls were places where boys secluded in the growth-houses could go to cleanse their faces and eyes (compare Meggitt 1964:211-13 on Enga practices of washing the eyes in spring-water pools within seclusion areas for bachelors undergoing maturation rituals). Behind waterfalls, on ledges, special magical plants used in the sacred practices of growth (palena) were sometimes found. Again, the images are a metaphor for, or are indicative of, the context of initiation, an evocation of the enchantment of initiation.

Another pikono (Stewart and Strathern 2002a:136-37) begins with a similar set of images of waterfalls or rushing water:

I sing of the man Yerepi Rangerakini

As we sit here and I tell you the story

Yerepi stayed at the place Kali

Where the water rushes and makes a noise

He stayed at the place Atili,

Where the water rushes and makes a noise

At the place Mali, where the water rushes

There he stayed, he was an orphan

Here the rushing of the water might be taken as indicative of the lonely existence of the boy. In the Duna area many rivers run underground in limestone caves, rushing out from these in places. The rushing water both evokes the isolation of the places where the boy stays, and the sense of his own movements from place to place as he sets out on his journey of exploration (on which he discovers a cannibal giant, an auwape, who teaches him how to eat human flesh: Yerepi Rangerakini's lack of a human family of parents seems to lead him in this direction) (see Stewart and Strathern 2002b; Strathern and Stewart 2004). The names of the places here, in the mise en scène of this narrative, appear in triplicates (Kali, Atili, Mali, and later — not quoted here-Apima, Ateli, Akepi).

These examples, like the example of the bows, appear as rhythmic and repetitive lists, lending themselves to a mnemonic function. Since they represent a journey, they also function as a partial map of the landscape, assuming knowledge on the part of the listeners, but also teaching and preserving it in the pikono form.

In pikono we find very strongly the function of preserving knowledge through repetition. Pikono also include many archaic and poetic words not used in everyday conversation, and these too may appear in lists, of different names for kinds of plants in the environment at large.

Kang rom seem to build interest in startling metaphors of actions; pikono in intense metonymic representations of landscapes. Poetic traditions may specialize 
differently in their appropriations from the magical potentialities of language, as Tambiah's work indicates (Tambiah 1968). We compare our Melpa and Duna examples now with Hesiod and Virgil.

\section{Hesiod: Didactic images and mythopoetic narrative}

The poet Hesiod is thought to have lived during the eighth and seventh centuries BCE (Athanassakis 2004:xi). He composed his works in the same hexameter form as used in the Homeric epics. According to his own account, he was looking after his sheep near Mt. Helikon in rural Boeotia when the Muses met him and bestowed on him "the gift of song" (ibid.:xi). His brother Perses, Hesiod claimed, tried to cheat him out of his portion of their father's land. Hesiod composed his Works and Days (Erga kai Hemerai) in order to teach his brother the proper ways of both farming and morality.

Athanassakis viewed Hesiod as a poet in the great traditions of oral composition, in which "creative performance, and powerful memory help the singer compose in a style that is largely formulaic ... Meter helps him fuse formulaic and nonformulaic language ... Each performance is unique" (ibid.:xiv). But Athanassakis thinks that the Greek alphabet and, with it, writing practices had reached Boeotia by Hesiod's time, and so "the question of mixed composition, oral for some themes, not so oral for other themes, must claim the attention it deserves" ( $p$. xvi). Athanassakis further points out that Hesiod mixes practical advice with cosmological expositions and flights of fancy (p. xvii).

Kang rom and pikono are narrative poetic forms. They encapsulate much practical and cultural information within the integuments of their narratives, as we have seen above. With Hesiod's Works and Days (and with Virgil's Georgics), we find a different combinatory pattern, although the basic combination of poetic song and factual information is at the core of all four of our cases. Unlike the two examples from Papua New Guinea, Hesiod's work is explicitly didactic, and he foregrounds himself as the speaker and narrator. In kang rom and pikono, the singer, as performer and creator, is there and is addressing the listeners from time to time, but is not foregrounded. Hesiod's own sententious voice, by contrast, is heard throughout.

He that wrongs another man wrongs, above all, himself, and evil schemes bring more harm on those who plot them.

(Works and Days, lines 265-66; Athanassakis 2004:71)

So, beware Perses!

On the practical side, Hesiod is full of advice, from ploughing time till harvest: 
Sung Tales from the Papua New Guinea Highlands

early risers harvest fields laden with grain.

Plow in the spring. Fallowed land plowed in the summer will produce.

Sow fallow land when the soil is still loose;

such land will spare you curses and the clamor of hungry children.

(Works and Days, lines 461-64; Athanassakis 2004:76)

This is all straightforward, unvarnished, specification. But often Hesiod gives dramatic descriptions of harsh weather, for example:

when Thracian gusts whip thick clouds to frenzy

(Works and Days, line 553; Athanassakis 2004:79)

Or of summer, when:

the thistle blooms and the chirping cicada

sits on trees and pours down shrill song.

(Works and Days, lines 582-83; Athanassakis 2004:79)

Taboos must be observed:

Let those who drink never place the serving cup

over the mixing bowl; bad luck comes with this, too.

(Works and Days, lines 744-45; Athanassakis 2004:83)

Finally:

The same day can be a mother now, a stepmother later.

Happy and blessed is the man who knows all this

and does his work without offending the immortals,

ever watching birds of omen, ever shunning transgression.

(Works and Days, lines 825-28; Athanassakis 2004:85)

Hesiod mixes mythological references, practical advice and knowledge, and moralistic warnings and admonishments, all together in his rolling hexameters. Tucked into his poem is a farmer's seasonal manual. Narrative as such is secondary to didactics. In the New Guinea ballads, didactics are secondary to narrative entertainment, although moral points are certainly made. 


\section{Virgil: The life of the bees}

Virgil (Publius Vergilius Maro) was born in 70 BCE near Mantua in Italy. He was dispossessed of his family farm after the assassination of Julius Caesar in 43 BCE and the defeat of Brutus and Cassius at the battle of Philippi (Fairclough 1956:ix). Later, with the help of the Emperor Octavius, he "either recovered his farm or received in compensation an estate in Campania" (ibid.:x); hence, Virgil's interest in rural farming.

Virgil adorns his descriptions of farming practices with numerous observations of a more philosophical sort. Hesiod is didactic in the narrower sense of giving technical formulae for times to plough, sow, and reap, and also in terms of his overall linkage of hard work with proper morality. Virgil, less concerned with moralistic homily, but equally immersed in the world of mythology inherited from the Greeks, has much to say on how, for instance, to handle hives of bees. $\mathrm{He}$ describes the famed division of labour among the hive's inhabitants, for example the bees that act as "sentries":

Sunt quibus ad portas cecidit custodia sorti,

Inque vicam speculantur aquas et nubila caeli,

Aut onera accipiunt venientum aut agmine facto

Ignavum fucos pecus a praesepibus arcent,

Fervet opus redolentque thymo fragrantia mella

There are those to whom falls the lot of guarding the gates,

In turn they watch for rains and clouds in the sky

Or take the loads of arrivals, or in military line

Drive out from the precincts the idle crew of drones

The place bustles with work and the fragrant honeycombs smell of thyme.

(Georgics IV, lines 165-69; translation, Andrew Strathern)

The commitment of the bees to their communal enterprises is lauded by Virgil in the famous aphorism where he explains that individual bees do not live beyond their seventh summer, but as a result of their combined efforts:

At genus immortale manet, multosque per annos

Stat fortuna domus, et avi numerantur avorum.

Their line remains immortal, and through many a year

The fortunes of their house stand firm and genealogies grow long.

(Georgics IV, lines 208-9; translation, Andrew Strathern) 
Finally, Virgil appends a further cosmological statement, to effect that the bees have in them an element of the divine:

deum namque ire per omnia, terrasque tractusque maris caelumque profundum; Hinc pecudes, armenta, viros, genus omne ferarum Quemque sibi tenuis nascentem arcessere vitas

for divinity is said to go through all things

Lands and the expanses of the sea and the deep sky

From it the flocks and herds and the wild beasts and men themselves

Draw the source of their slender life-breath.

(Georgics IV, lines 221-24; translation, Andrew Strathern)

And in the end, through this divine power, all things return to their place among the stars, Virgil proclaims (ibid., lines 225-27).

Like the ballad singers of Papua New Guinea, Virgil uses his poetic skills to blend together much practical information with flights of narrative fancy; and, as we have seen, he weaves elements of a cosmology into this.

\section{Conclusion: Magical language}

The language of these master singers is certainly "magical," in the sense that it has the power to evoke scenes and draw from these both narrative pathos and a wider sensibility about life in general. Stanley J. Tambiah, in his examination of magical language in the more specific sense of spells used for instrumental purposes, formulated things very well:

It is clear that the spells and myths contain information, which is not the remains of archaic beliefs, but a living knowledge related to technological and social activities. (Tambiah 1968:193)

And, on magical language:

It ingeniously conjoins the expressive and metaphorical properties of language with the operational and empirical properties of technical activity. (Tambiah 1968:202)

What Tambiah wrote here about magical language, in the more specific sense, applies equally to the poetic language of the artistic creators or creations that we have discussed here. And to this we have added that, just as the words of 
Hesiod and Virgil encode worlds that are lost to us in the contemporary world, so the balladic records of the Western and Southern Highlands encapsulate a dynamic series of life patterns which, if the genre survives, will similarly turn into heritage over time. And with the sense of heritage will come the technical and practical knowledge that composes it. ${ }^{1}$

Peter Fallon, an Irish writer, has made a creative and vigorous translation of the Georgics, and he comments on the question of "local knowledge":

The more closely I read the poem, the more I grew amazed at all that Virgil ... knew. (Fallon 2004:125)

Virgil and his companions studied emplaced knowledge:

How attentive and responsive they were to their environment. The sureness of their knowledge was the fruit of observation ... still, beside their faiths, they preserved room for mystery. (Fallon 2004:125)

What Fallon wrote here of Virgil applies well to the singers of the kang rom and pikono. $^{2}$

\section{Acknowledgements}

We would like to thank Liz and Ralph Sheppard for their stimulating conversations over the years and especially while we were staying with them in County Donegal, Ireland, in 2007 during the "wet" phase of June while we were writing sections of this essay. We thank them also for their concern for the environment and their healthy "humanistic" perspectives. We would like especially to thank all our interlocutors, helpers, and assistants in Papua New Guinea, who have been part of our research projects and programmes over many years and have worked with us on balladic materials in the Melpa and Duna areas.

\footnotetext{
1 Our interest and work on "heritage" issues extends across our regional interests, see, for example Strathern and Stewart 1998, 2005c. We were also the co-organizers of an international conference entitled "Landscape, Heritage, and Conservation" held in March of 2008 at the University of Pittsburgh under the auspices of the European Union Center of Excellence in the University Center of International Studies. The publication from this conference is entitled Landscape, Heritage, and Conservation: Farming Issues in the European Union (Stewart and Strathern 2010). Also, in general, wü̈ amb rakl noman tenda pilik mangkona pek nggi ningk morombil e kin, e ukl kai we na ama rondokl ti orandorombil.

2 The same must be said for the untold numbers of singers and creators of epics and ballads in largely oral contexts across the world. One stream of tradition, composition, and skilful oral performance that we have recently begun to study is found in the Korean genre of $p$ 'ansori sung epics, which may have partly been rooted in shamanic ritual performances, but developed as an art of entertainment, exemplifying the same magical potentialities of language that we identify in kang rom and pikono (see Park 2000; Pihl 1994; Walrave 1994). We participated in a performance of $p$ 'ansori in Taitung, Taiwan, in 2003 and another in Seoul, South Korea, in May 2005, observing and recording the events. A fuller account of this research is forthcoming.
} 
We also thank Prof. Huang Shu-min, director of the Institute of Ethnology, Academia Sinica, Taipei, Taiwan, for his assistance and support of our research during our stay as visiting research fellows from 21 December 2006 through 8 March 2007. Parts of this essay were worked on while conducting research in Taiwan during 2007. We also thank our colleagues at the Institute of Ethnology and those at the Dong-hua University in Hualien for their intellectual engagements with us during this period of time and in earlier years.

\section{References}

Athanassakis, Apostolos N., trans. 2004. Hesiod: Theogony, Works and Days, Shield. Baltimore and London: John Hopkins University Press.

Fairclough, H. Rushton, trans. 1956. Virgil: Eclogues, Georgics, Aeneid I-VI. Loeb Classical Library. London: William Heinemann Ltd. (Orig. pub. 1916)

Fallon, Peter. 2004. The Georgics of Virgil. Translated by Peter Fallon. Loughcrew, Ireland: Gallery Press.

Meggitt, Mervyn J. 1964. "Male-female Relationships in the Highlands of Australian New Guinea." American Anthropologist, n.s., 66 (4), pt. 2: 204-24.

Park, Chan. 2000. “'Authentic Audience' in P'ansori, a Korean Story-telling Tradition." Journal of American Folklore 113 (449): 270-86.

Pihl, Marshall R. 1994. The Korean Singer of Tales. Cambridge, MA: Council of East Asian Studies, Harvard University.

Sørensen, Jesper. 2007. "Malinowski and Magical Ritual." In Religion, Anthropology, and Cognitive Science, edited by Harvey Whitehouse and James Laidlaw, 81-104. Ritual Studies Monograph Series. Durham, NC: Carolina Academic Press.

Stewart, Pamela J., and Andrew Strathern. 2000. Speaking for Life and Death: Warfare and Compensation among the Duna of Papua New Guinea. Senri Ethnological Reports, 13. Osaka: National Museum of Ethnology.

2002a. Gender, Song and Sensibility: Folksongs and Folktales in the Highlands of New Guinea. Westport, CT: Praeger.

. 2002b. Remaking the World: Myth, Mining and Ritual Change among the Duna of Papua New Guinea. Smithsonian Series in Ethnographic Inquiry. Washington, DC: Smithsonian Institution Press. 
, eds. 2005a. Expressive Genres and Historical Change: Indonesia, Papua New Guinea and Taiwan. Anthropology and Cultural History in Asia and the Indo-Pacific Series. Hants: Ashgate.

. 2005b. "Duna Pikono: A Popular Contemporary Genre in the Papua New Guinea Highlands." In Expressive Genres and Historical Change: Indonesia, Papua New Guinea and Taiwan, edited by Pamela J. Stewart and Andrew Strathern, 83-107. Anthropology and Cultural History in Asia and the Indo-Pacific Series. Hants: Ashgate.

, eds. 2010. Landscape, Heritage, and Conservation: Farming Issues in the European Union. European Anthropology Series. Durham, NC: Carolina Academic Press.

Strathern, Andrew, and Pamela J. Stewart, eds. 1998. Kuk Heritage: Issues and Debates in Papua New Guinea. Department of Anthropology, University of Pittsburgh.

- 2000. Arrow Talk: Transaction, Transition, and Contradiction in New Guinea Highlands History. Kent, $\mathrm{OH}$, and London: Kent State University Press.

2004. Empowering the Past, Confronting the Future: The Duna People of Papua New Guinea. Contemporary Anthropology of Religion Series. New York: Palgrave Macmillan.

. 2005a. "Introduction." In Expressive Genres and Historical Change: Indonesia, Papua New Guinea and Taiwan, edited by Pamela J. Stewart and Andrew Strathern, 1-39. Anthropology and Cultural History in Asia and the Indo-Pacific. Hants: Ashgate Publishing.

. 2005b. "Melpa Songs and Ballads: Junctures of Sympathy and Desire in Mount Hagen, Papua New Guinea." In Expressive Genres and Historical Change: Indonesia, Papua New Guinea and Taiwan, edited by Pamela J. Stewart and Andrew Strathern, 201-33. Anthropology and Cultural History in Asia and the Indo-Pacific. Hants: Ashgate Publishing.

_. 2005c. " "The Ulster-Scots': A Cross-border and Transnational Concept and Its Ritual Performance.” Journal of Ritual Studies 19 (2): 1-16.

_ 2007a. "Ritual Studies and Cognitive Science: Anthropology's Shifting Boundaries." Preface in Religion, Anthropology, and Cognitive Science, edited by Harvey Whitehouse and James Laidlaw, ix-xxi. Ritual Studies Monograph Series. Durham, NC: Carolina Academic Press. 
- 2007b. "Songs, Places, and Pathways of Change: Themes from the Highlands of Papua New Guinea." In "Anthropo-aesthetic Domains: Song, Dance, and Landscape," special issue, Taiwan Dance Research Journal 3: $1-26$.

Tambiah, Stanley J. 1968. "The Magical Power of Words." Man, n.s., 3 (2): $175-208$.

Walrave, Boudewijn. 1994. Songs of the Shaman: The Ritual Chants of the Korean Mudang. London and New York: Kegan Paul International. 